\title{
Determining of Parking Lot Area Policy Using System Dynamic Simulation Approach
}

\author{
Intan Berlianty \\ UPN "Veteran" Yogyakarta
}

\author{
Yuli Dwi Astanti \\ UPN "Veteran" Yogyakarta \\ yuli.upnyk@yahoo.com
}

\author{
Irwan Soejanto, Eka Febriani S \\ UPN "Veteran" Yogyakarta
}

\begin{abstract}
Parking lot is one of the important public facilities for all people because of its function to accommodate the stopping vehicles. However, because of its limited parking area, a lot of vehicle users park their vehicles at side of the road. It resulted in street problems because the road become narrower and this creates stuck traffic jam. Sleman, one of five districts in Yogyakarta Province,has heavy stuck traffic jam due to the narrow road. The problem arises when many people park their vehicles at the side road. One of the dense parking area in Sleman District is Babarsari Road, Gejayan Road, and road in Ambarukmo areas. Stuck traffic jam get worse due to increasing vehicle numbers and limited parking area available. The increased vehicle numbers are influenced by many dynamic variables. Therefore, an approach to formulate and adopt policy for dynamic parking side area is seriously needed.This research was conducted to analyze the existing parking area width. The purpose of this study is to offer accurate recommendations to improve parking area capacity by using system dynamic simulation approach. The research was startedon understanding the real system in formulating causal loop diagram and stock and flow diagram to understand interactive relationship among variables. Following this matter, two scenarios were made to get recommended policy in order to accommodate side road parking area width to reduce stuck traffic jam. From two proposed scenarios, it was found that the second scenario was the best recommendation with the least error score.
\end{abstract}

Keywords: simulation, on street parking, system dynamic

\section{INTRODUCTION}

Sleman district is one of five regional areas of Yogyakarta Special Province (DIY). Slemanis the largest area totaling $574,82 \mathrm{~km}^{2}$ with population density op to 1.901,66 lives $/ \mathrm{km}^{2}[1]$. According to Long Term Development Plan year 2016-2021, trade, hotel and restaurants increase of $4,27 \%$ in which it indicates that people's need increase as well. One of areas in Yogyakarta with rapid development in the trade sector is on Jalan Babarsari, Jalan Gejayan, and Ambarrukmo area. In recent years, there are many stores are built. The emergence of these stores attract visitors to stop. Ideally, the store owner should provide an off-street parking area. The parking area can be located in the yard of a place or inside the building, for example, in the basement. However, due to the unavailability of suitable parking lots, visitors choose to park their vehicles on the shoulder of the road or known as roadside parking. The existence of roadside parking reduces existing roads, causing roads to become narrower and crowded. Related to the jamming traffic, the existence of roadside parking often gives negative impact. In addition, people mostly did not aware of the effect. In some cases, if sidewalks were not provided, pedestrians are forced to walk on roads. In turn, it can be dangerous and uncomfortable. Then, the traffic may be disrupted.

There are several factors that causepeople park on the roadside. These factors include the growth of stores and other public facilities. Each location has different capacity in accommodating the vehicle. The type of vehicle also became a determinant factor. It determined the number of vehicles that can be accommodated in certain place. Some of those factors are dynamic variables. Furthermore, an approach to accommodate the situation is required.

Research on roadside parking area analysis has been conducted before [2]. The research was trying to know the effect of roadside parking activities on the performance of the road segment. The purpose of this research was to know the reduction of the capacity and the increasing of road usage due to the curbside parking during peak hour and to conduct simple economic analysis to income from on-street parking. It was found that, if on-street parking is moved to off-street, the losses experienced by road users can be eliminated. Moreover, the gains received by the operator (the government) become bigger due to the progressive fare of off-street parking.

Another research tried to analyze the needs of parking area at the Regional General Hospital Prof. Dr. W. Z. Johannes Kupang [3]. The purpose of the study was to determine the needs of parking area based on existing conditions in the hospital. The results of the study showed that the given/ provided parking site was incapable to accommodate the number of the vehicles. 
The researcher suggested that using a certain slope can maximize the use of parking space.

Starting from those previous researches, this research tries to solve the problem with system dynamic approach. System dynamic can describe real systems with elements that change over time and it can solve a complexity of problems that are difficult to resolve accurately. The result of this research is the recommendation of parking area policy that can overcome the congestion caused by roadside parking.

\section{Parking Definition \\ METHOD}

Parking has a definition of stopping or putting the vehicle for a while in the space provided. Thus, the parking area can be regarded as a special place for the vehicle to stop for safety. One of the criteria a person choosing a parking location is accessibility. If the parking area is too far away from the destination, people will move to another place. It is important to place the parking location as close as possible to the destination of the trip [4]. Parking management is included in the strategy variation in order to improve parking efficiency, parking quality for parking users, and design of parking facility [5]. In general, parking can be divided into two classes based on location and user. The location based parking consists of two kinds of parkings, such as: onstreet parking (at the roadside) and off-street parking (special purpose parking facility). Barter also suggests that part of parking management at the road side includes characteristics, location, time and duration of parking at the roadside.

\section{System Dynamic Simulation}

Simulation is an imitation of a manually or computer-made manifest system, which is then observed and summarized to study the characterization of the system. [6]. The simulation steps are as follows [7]:

1. System definition: Determining the limits of the system and variable identification.

2. Model formulation: Formulating the relations intercomponents of the model.

3. Data collection: Identifying data needed by the model conforming the purpose of the model making.

4. Model building: Involving preparation that needs adjustment with simulation language that used.

5. Model verification: Process of checking the model for errors.

6. Model validation: Process of model testing whether the model already fit the real system.

7. Scenario building: Making some scenarios (experiments) in order to fix system performance.

8. Model interpretation: Drawing conclusion from the output of the simulation model.

9. Implementation: Implementing model to the system.

10. Documentation: The process of compiling the model output.

System Dynamic is a method to strengthen learning in a complex system which partly becomes a method to create a management flight simulator, a computerized simulation model. Its purpose is to provide an assistance to learn dynamic complexity, understand sources of policy resistance, and design more effective policy [8]. Two model diagrams are available to elaborate System Dynamic model:

Causatic diagram. Causatic diagram can describe causal relationship among intersystem variables. Flow polarity is divided into positive $(+)$ and negative (-). It is called positive flow polarity when variable change in the initial slow causes the increase of variable value in the end of the flow. On the other hand, it is called negative when variable change in the initial flow causes variable value reduction in the end of the flow (contrast).

Flow diagram. Flow diagram in the simulation describes intervariable relation and is stated in symbols. This research was conducted on Babarsari Road, Gejayan Road, and west through south of Plaza Ambarrukmo. The locations were chosen based on the recommendation of Parking Integrated Serving Unit of Transportation Department of Sleman on high public roadside. High contract value reflects high visit level. Research timing in each location is based on their corresponding busy hours with single shift data collection slot through a single slot. The highest volume of vehicles parked is during busy hours.

\section{Developing Simulation Model}

Development of simulation model in this research is conducted to determine the right policy in the provision of parking area in Sleman. Data processing stages in this study are described in the following steps:

1. Identify the roadside parking problems in Sleman

2. Determine the dominant factor to the problems that occur

3. Identify the system by designing causal loops and influencing variables.

4. Design stock and flow diagrams

5. Simulate using Powers in software

6. Perform verification test and validation test

7. Plan a repair system. Determining of the policy of parking area provision in order to prevent roadside parking is completed through several scenarios, namely among others:

Scenario 1: add $2 \%$ and $5 \%$ more road segment

Scenario 2: change parking space unit of the vehicle

8. Implement the improvement scenario. Compare onstreet parking space in use and the recommended land area to be provided.

9. Organize documentation and report the results

\section{RESULT}

This study was conducted on roadisde parking area in Sleman district, Yogyakarta. The information obtained from this research will provide a recommendation to the local government on roadside parking problems. It is hoped that it can reduce the existing of roadside parking. 
The data required from this study includes units of parking space for both cars and motorcycles, the number

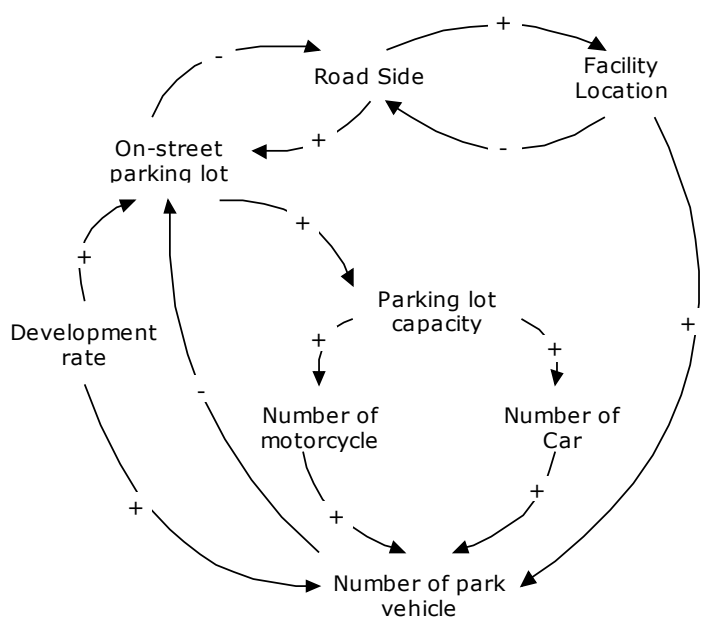

Figure 1. Causal loop diagram

of vehicles parked in one shift, and the roadside used.

This research was conducted to get recommendation on the width of roadside parking area using system dynamic approach. A Causal Loop Diagram (CLD) is completed first in order to find variables that affect each other. CLD or cause-and-effect diagrams explain causal relationships that affect and become the result of roadside parking. This diagram became the basis for the construction of stock and flow diagrams in system dynamic. The resulting causal diagram of the roadside parking problem is illustrated in Figure 1.

Figure 1 shows that in determining on-street-parking area there are interrelated variables, either directly or indirectly. Relationships between variables are mutually reinforcing (positive) or mutually debilitating (negative). An example of mutually reinforcing variable says, the higher the rate of the development growth, the higher the need for parking area. However, in terms of mutually debilitating, for example, the more vehicles the less parking capacity.

When CLD is completed, Stock and Flow Diagram (SFD) is prepared to create formulations and relationships between variables, and then the model created is validated. SFD is a visualization of real system model development that is provided in Powersim software. SFD is represented by level, auxiliary, constant and rate variables. In the variable there is a mathematical formula, so that after the model is run, SFD can provide information based on research needs. The SFD used in this study is described in Figure 2.

SFD that has been built is then validated. Validation stage compares actual data with the simulation results by using Powersim for the same component. Validation is performed for all research sites, for example validation between actual data of number of motorcycle parking in Babarsari and result of simulation of Babarsari area. Table 1 explains the comparison between the actual number of motorcyle parking in Babarsari with the simulation results.

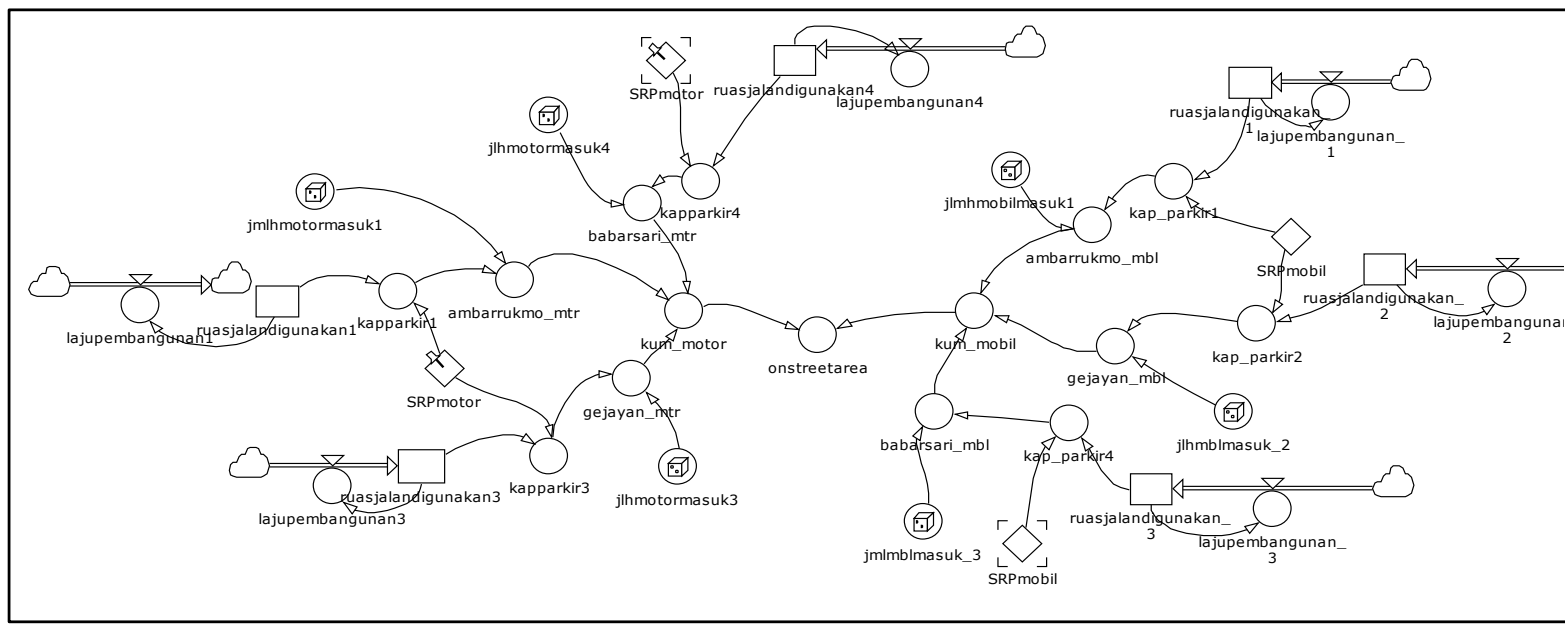

Figure 2. SFD 
Table 1. Actual and simulation data output comparison

\begin{tabular}{ccc}
\hline & \multicolumn{2}{c}{ Number of motorcycle } \\
No. & $\begin{array}{c}\text { Actual } \\
\text { Data }\end{array}$ & $\begin{array}{c}\text { Simulation } \\
\text { Result }\end{array}$ \\
& 1616 & 1605.15 \\
1 & 1658 & 1399.84 \\
2 & 1442 & 1448.83 \\
3 & 1458 & 1570.59 \\
4 & 1408 & 1593.95 \\
5 & 1458 & 1593.86 \\
6 & 1492 & 1643.86 \\
7 & 1522 & 1589.82 \\
8 & 1614 & 1577.32 \\
9 & 1574 & 1634.19 \\
10 & 1492 & 1439.96 \\
11 & 1512 & 1493.29 \\
12 & 1574 & 1516.27 \\
13 & 1492 & 1488.75 \\
14 & 1536 & 1561.05 \\
15 & & \\
Rata & 1523.20 & 1543.78 \\
\hline -rata & &
\end{tabular}

mean comparison

$\mathrm{E} 1=\frac{(S-\bar{A})}{\bar{A}}=\frac{(15143.778-1523.20)}{1543.78 .20}=1.381 \%$

Since value of $\mathrm{E} 1 \leq 5 \%$, then model is stated as valid. After mathematical validation using mean comparison, validation of the structure is tested by experts from the Parking Division of Transportation Office of Sleman Regency to ensure that the model is made in accordance with the existing real system in the field. The result of structural validation by experts is in Table 2 .

Table 2. Model validation by experts

\begin{tabular}{|c|l|c|}
\hline No. & \multicolumn{1}{|c|}{ Description } & Validasi \\
\hline 1. & $\begin{array}{l}\text { The rate or level of development } \\
\text { willaffect the existing road segment }\end{array}$ & Valid \\
\hline 2. & $\begin{array}{l}\text { The size of the road that is used affects } \\
\text { the parking capacity }\end{array}$ & Valid \\
\hline 3. & $\begin{array}{l}\text { Parking capacity is affected by vehicle } \\
\text { parking space unit }\end{array}$ & Valid \\
\hline 4. & $\begin{array}{l}\text { The number of vehicles that can be } \\
\text { accommodated in each location is } \\
\text { affected by the parking capacity and the } \\
\text { number of vehicles parking. }\end{array}$ & Valid \\
\hline
\end{tabular}

The simulated model is valid and can be used to give recommendation by constructing scenario. The scenario that built was done to give an accurate parking area recommendation in order to overcome roadside parking area. The first proposed scenario is to add the road segment. The addition is about $2 \%$ to $6 \%$ of existing roads. This scenario aims at increasing the parking capacity so that more vehicles can park in proposed place. The addition can be done on the right or left side of the parking area, as well as adding overall.
After building Scenario 1, Scenario 2 was developed by changing the units of motorcycle and car parking space. The modified aspect of the motorcycle parking space is the distance between the rear of the motorcycles which was initially $20 \mathrm{~cm}$, was changed to $10 \mathrm{~cm}$. For car parking space changes were made in the space behind and front, and the space to open the door. Finally the parking space used is 1.33 $\mathrm{m}^{2}$ for the motorcycles and $10.9 \mathrm{~m}^{2}$ for the cars. It is shown in Table 3.

Table 3. Unit of Parking Space

\begin{tabular}{|c|c|c|}
\hline Vehicle & Unit Before $\left.\mathbf{( m}^{\mathbf{2}}\right)$ & Unit After $\left.\mathbf{( m}^{\mathbf{2}}\right)$ \\
\hline Motorcycle & $0,75 \times 2=1,5$ & 1,33 \\
\hline Car & $2,3 \times 5=11,5$ & 10,9 \\
\hline
\end{tabular}

\section{CONCLUSION}

From the construction of two scenarios to the real system, the second scenario was chosen as a recommended scenario. The scenario is to change the size of parking space of motorcycles and cars. Initially, $1.5 \mathrm{~m}^{2}$ and $11.5 \mathrm{~m}^{2}$ were provided respectively, and it changed into $1.33 \mathrm{~m}^{2}$ and 10.9 $\mathrm{m}^{2}$, respectively. Statistical test shows that the scenario has the smallest error value. From this scenario, the total area recommended is $23,160 \mathrm{~m}^{2}$ for motorcycles and $1,269 \mathrm{~m}^{2}$ for cars. Such scenarios may be an appropriate choice since it is easier to adjust the parking space rather than to expand the parking space.

Acknowledgement: This paper is part of a research entitled "Model Development and On-street Parking Revenue Simulation to Increase Locally-Generated Revenue: A Case Study in Sleman District" funded by the DIKTI Applied Product Research Grant in 2018.

\section{REFERENCES}

[1] Statistc Center Bureau. Population Data of Sleman Regency, Jakarta. 2015.

[2] Patmadjaja, H., Setiawan, R., Urbanus, J., and Tjahjaputra, P. Pengaruh Kegiatan Perparkiran di Badan Jalan Terhadap Kinerja Ruas Jalan (Studi Kasus Jalan Kertajaya), Dimensi Teknik Sipil, Vol. 5.,page. 63-74. 2003.

[3] Messah, Y, A., Kanny, R, A, E, L., and Rizal, A,H. Analisis Kebutuhan Lahan Parkir Di Rumah Sakit Umum Daerah Prof. Dr. W.Z. Johannes Kupang. Jurnal Teknik Sipil Vol. 1 No. 4 September 2012.

[4] Barter, P.On-Street Parking Management, Deutsche Gesellschaft fur Internationale Zusammenarbeit (GIZ). 2016.

[5] Banks, J., Carson, J. S., Nelson B. L., danNicol, D. M.Discrete-Event Sysem Simulation, Prentice Hall, New Jersey, United States of America. 2006.

[6] Suryani, E. Pemodelandan Simulasi, Graha Ilmu, Yogyakarta, Indonesia. 2006.

[7] Sterman, J. D. Business Dynamics: System Thinking and Modelling for A Complex World, The McGraw Hill Companies Inc., Boston. 